\title{
ON THE DIVERGENT FORMS AT PRESENT INCORPORATED IN THE FAMILY MELANIID无.
}

By J. E. S. Moore.

Read 9th December, 1898.

Is his great work on the Morphology and Classification of the Prosobranchiata, Bouvier ${ }^{1}$ showed, after a study of several examples of true Melaniidæ and of the Cerithiidæ, that it is impossible on purely anatomical grounds to separate the one from the other, and he has made it evident at the same time that within the Melaniidæ as a whole there are forms which in their morphological characters are widely divergent from one another. Bouvier has described in some detail the anatomical peculiarities of Melania amarula (Linn.), Lamarck's type of the genus, $M$. costata, Quoy \& G., M. filocarinatu, Montf., M. tuberculata, Müll., and $M$. asperata, Lam.

Through the courtesy of my friend Mr. Edgar Smith, I have been able to examine a number of other Melanias, and we have consequently now at our disposal a sufficient body of morphological facts to enable us to discuss with profit the inter-relationships of these forms.

A large number of the genera and subgenera which are at present included in the Melaniidæ have never been examined anatomically, but have been referred to this family with $M$. amarula (Linn.), solely on the characters of their shells.

On this account it will be found, in the succeeding survey, that Bouvier's statements, ${ }^{2}$ firstly, that purely conchological determinations are always to be regarded as more or less distinctly hypothetical, and secondly, that "deux coquilles indentiques peuvent protéger des animaux fort différents," are both quite true; and lastly, we shall see that his conclusion, "la famille des Mélaniides est une des plus mal établiés dans tout le groupe des Prosobranches, elle est pour ainsi dire basée sur les habitats des genres qui la composent," rather underthan over-estimates the present unsatisfactory systematic aspect of the group.

Bouvier found that in $M$. amarula (Linn.) the nervous system is constructed on a plan which is characteristic of a large group of Prosobranchiata, including many families besides the Melaniidæ. In this form the cerebral ganglia are closely applied to each other, while the pleural ganglia are equally closely applied to them beneath, or rather immediately behind. On each side the great pallial nerves have two separate roots, which anastomose in the bodywall, and thereby give rise to what Bouvier has termed the dyaloneurous

1 Ann. Sci. Nat., ser. xvir, tom. iii (1887).

2 Tom. cit., p. 130. 
type of nervous sytem. The cerebro- and pedo-pleural connectives are not long, and the pedal ganglia possess no scalariform pedal cords.

This type of nervous system is encountered in the Cerithiidæ, and in a slightly modified form among the Turritellidæ, the Typhobiidæ, the Strombidæ, the Aporrhaiidæ, and the Xenophoridæ.

In the genus Melanopsis, on the other hand, Bouvier found that the nervous system is widely different, being much more comparable to that met with in the genera Vivipara, Cyclophorus, and their allies. Thus, among the different animals which have hitherto been considered as sufficiently closely related to form the members of a single family, we find types of organization that are singularly diverse. For purely conchological reasons three genera of mollusca occurring in Lake Tanganyika, namely, Nassopsis, Paramelania, and Typhobia, have also, until lately, been regarded as belonging to the Melaniidæ; and since I have had an opportunity of fully examining the anatomical characters of these forms, it will be of interest to review in the light of Bouvier's work the conclusions to which my researches have led.

In a recent paper ${ }^{1}$ I have described the anatomy of Typhobia in detail, with that of the allied Tanganyikan genus Bathanalia, and have therein made it evident that both these syphonate gastropods differ almost as widely from Melania amarula in one direction as Melanopsis does in another. In Typhobia and Bathanalia the nervous system is on the same general plan as in Melania amarula, or in Aporrhais; but in its general anatomy, as for example in its radula, Typhobia corresponds much more closely to the latter than to the former of these two genera. I was thus led to dissociate Typhobia and Bathanalia altogether from the Melaniidæ, and place them in a new family, the Typhobiidæ, which, in its general anatomical characters, finds its nearest relations in Strombus and the Aporrhais group.

Nassopsis, a full account of the anatomy of which will, I hope, shortly appear in the Quart. Journ. Micros. Sci., exhibits yet another type of nervous system, the cerebral ganglia being widely separated from each other. The pleural ganglia are separated from, and are distinctly below, the cerebral ganglia, as in Vivipara; but the right pallial nerve, instead of originating in two roots, as in the latter genus, here springs as a single trunk from the sub-intestinal ganglion, which is put into direct connection with the pleural ganglion by a stout cord. Thus Nassopsis is, according to Bouvier's definition, strongly zygoneurous on the right side.

These peculiarities, however, are not the only differences between this and the preceding types. We find that in Nassopsis the cerebral ganglia are secondarily united by a very distinct labial commissure, just as in the Rhipidoglossa and such Archi-taenioglossa as Ampullaria and Vivipara, and to make the homology between the nervous system of Nassopsis and the more primitive Archi-taenioglossa complete, we find further that the pedal ganglia are continued backward into long

1 Quart. Journ. Micros. Sci., vol. xli (1898), p. 181. 
scalariform pedal cords. ${ }^{1}$ Moreover, we find in Nassopsis that the buccal mass and the salivary glands are similar to those of Littorina or Vivipara, while the stomach is extremely peculiar. This organ is in the first place divided into two chambers, into one of which the œsophagus, intestine, and liver open, while the other has thick walls, is lined internally with a singularly iridescent membrane, and contains an almost globular crystalline style. Furthermore, there appears on the postero-ventral wall of the stomach a spirally arranged valvular structure, which I am disposed to regard as homologous with the spiral cæcum so frequently present in the Rhipidoglossa.

Similar primitive features are exhibited in the genital apparatus, for we find that there are no accessory genital organs, and that the animal is viviparous.

Thus, so far from Nassopsis conforming to the true Melanian type, it is seen upon anatomical examination to be a highly peculiar and primitive form; a form which I believe to be on the whole more primitive and more typically representative of the Archi-tænioglossa than the genus Vivipara itself.

The existence in this tænioglossate of what I believe to be the rhipidoglossate spiral cæcum is something quite new, and must be regarded as of great interest in connecting the Archi-tænioglossa with the Rhipidoglossa.

I have already pointed out ${ }^{2}$ that the shell of Nassopsis, like so many of the halolimnic Tanganyikan types, is indistinguishable from the Jurassic Purpurina Bellona, D'Orb., so that, viewed from whatever side we will, Nassopsis appears persistently to be a form which has no connection with the Melaniidæ, and belongs to an extremely old type. I have, therefore, felt justified, at any rate for the present, in including it among the otherwise extinct Purpurinidæ.

In Bythoceras, another mollusc from the deep water of Lake Tanganyika, we have a form which, judged by the shell and operculum, appears to be closely related to the genus Paramelania. Paramelania has always been considered by conchologists to be closely related to Nassopsis; but if it bears any relation to Bythoceras - and the reverse is almost inconceivable-then it can have no affinities whatever with Nassopsis, because Bythoceras is found to have the general anatomy, the nerves, the alimentary canal, and pallial complex of the true Ceritho-Melanian group, while in certain features of its radula Bythoceras is almost indistinguishable from the marine genus Tympanotomus.

Thus it is apparent that the genera Typhobia, Bythoceras, Nassopsis, and Melanopsis not only differ as widely from each other as members of so many distinct families, but that, with the exception of Bythoceras, they bear not the slightest resemblance to the typical Melanian group, and must unquestionably be expunged from it.

1 It will have been noted that the European Vivipara is dyaloneurous in Bouvier's sense; but I find that in the Tanganyikan genus Neothauma (the generic distinction of which from Vivipara Dr. Pelseneer regards as superfluous), the right side of the nervous system is zygoneurous, as in Nassopsis.

2 Quart. Journ. Micros. Sci., vol. xli (1898), p. 303. 
Before, however, going further, it is advisable to discuss somewhat in detail the anatomical characters of some of the more typical members of the Melaniidæ.

In their admirable work, "Die Süsswasser-Molluscen von Celebes," the cousins Sarasin have divided the Melaniidæ into three 'untergrüppen,' namely, Paleo-, Neo-, and Tylo-Melania respectively, and these groups are distinguished mainly by the characters of their opercula and radulæ.

In the first series the radula has the conspicuous littorinoid character which is apparent in Melania episcopalis and the genus Pachychilus, while the operculum is multispiral.

In the Neo-Melanian group the radula has the peculiar features associated with forms more nearly related to Melania amarula; as, for example, Melania punctata (L.), and Melania tuberculata (Müll.), while the operculum is littorinoid.

Before receiving a copy of the Sarasins' work, I had been led, from a study of the soft parts and radulæ, to form conclusions which were somewhat similar to the above, and had made use of the terms Littorino- and Ceritho-Melania.

The third type described by the Sarasins appears to be peculiar to Celebes, not being represented among the African or the New World forms.

In Melania episcopalis we find that the radula-sac is long, that the salivary glands have the true littorinoid character, while the nerves, except in the probably unimportant feature of being more normally dyaloneurous on the right, are littorinoid too. There is, however, a remarkable development of the reproductive apparatus, in the form of a subcutaneous dorsal pouch, opening beneath the eye, and connected with the genital aperture by a groove corresponding, probably, to that present in the Opisthobranchs. So far as at present known, this condition is only met with elsewhere in the Tænioglossa among some closely allied Philippine species of Melania, and in the genus Tanganyicia, a form which, however, in many ways belongs to a totally distinct type. I am therefore led to the conclusion that the grooves and pouches are probably to be regarded as extremely primitive characters, and to be looked upon as the last remains among existing Prosobranchia of the grooves and introversible penes of the Opisthobranchia.

This opinion is strengthened by the fact that in the female Littorina and some other forms, such as Strombus, part of this accessory reproductive apparatus, the groove, still remains, although in these cases it appears to be quite without function.

The existence of this curious apparatus in $M$. episcopalis, therefore, does not necessarily at all dissociate it from the rest of the LittorinoMelanias in which the pouch is absent.

I have come, therefore, to the conclusion that it is in the highest degree probable the Littorino-Melanias (or Palæo-Melanias of the Sarasins) have arisen, independently from the Ceritho- or Neo-Melanias, as fresh-water derivatives of an old littorinoid group ; but it is clear that, if this be so, such conchological similarities as these two groups 
now exhibit are due merely to convergence, and are not real. To sum up : It appears that a number of forms, such as Typhobia, Bythoceras, Nassopsis, and Melanopsis, must unquestionably be excluded from the Melaniidæ, if that family is to be represented by the Melania amarula type, and they will have either to be incorporated into other totally distinct families or formed into new ones. It also seems that those forms which remain can be split up into the Littorino- and CerithoMelanias respectively, and that neither of these groups bears any near morphological relationship to the other.

Lastly, Bouvier, as noted, has already reduced the distinction between the Ceritho-Melanias and the Cerithiidæ to a vanishing point, by showing that apart from the characters of their shells the members of these families are not capable of being morphologically distinguished from each other. Family distinctions are, however, generally far greater than this even among the Prosobranchia, and it is only logical, therefore, that the Ceritho-Melanias, with their type, Melania amarula, should be bodily transferred to the Cerithiidæ as simply the freshwater contingent of that family.

This would necessitate the creation of a new family name for the littorinoid forms, if further investigation does not show, as it possibly will, that they must be transferred bodily to the Littorinidæ. 


\section{$2 \mathrm{BHL}$ Biodiversity Heritage Library}

Moore, J E S. 1899. "ON THE DIVERGENT FORMS AT PRESENT INCORPORATED IN THE FAMILY MELANIIDAE." Proceedings of the Malacological Society of London 3, 230-234.

View This Item Online: https://www.biodiversitylibrary.org/item/100098

Permalink: https://www.biodiversitylibrary.org/partpdf/202698

\section{Holding Institution}

Field Museum of Natural History Library

\section{Sponsored by}

Smithsonian

\section{Copyright \& Reuse}

Copyright Status: Public domain. The BHL considers that this work is no longer under copyright protection.

This document was created from content at the Biodiversity Heritage Library, the world's largest open access digital library for biodiversity literature and archives. Visit BHL at https://www.biodiversitylibrary.org. 